L.M. Lazarenko ${ }^{1}$, L.P.Babenko ${ }^{1}$, R.V.Bubnov ${ }^{1}$, O.M. Demchenko ${ }^{1}$, V.M.Zotsenko', N.V.Boyko', M.Ya. Spivak ${ }^{1,3}$

${ }^{1}$ D.K. Zabolotny Institute of Microbiology and Virology

of National Academy of Science of Ukraine,

154 Zabolotny St., Kyiv, 03143, Ukraine

${ }^{2}$ Uzhhorod State University of Ministry of Education and Science of Ukraine, 46 Pidgirna St., Uzhhorod, Transcarpathian Region, 88000, Ukraine

${ }^{3} L C L$ «Diaprof»,

35 Svetlichnogo St., Kyiv, 04123, Ukraine

\title{
IMUNOBIOTICS ARE THE NOVEL BIOTECH DRUGS WITH ANTIBACTERIAL AND IMMUNOMODULATORY PROPERTIES
}

This contribution deals with recently developed technology to obtain the novel biotech probiotic drugs on the basis of pre-selected and characterized strains of lactobacilli and bifidobacteria, which have antibacterial action and high level of ability to balance the immune response in infectious and inflammatory diseases of bacterial, viral and fungal origin by induction of various cytokines. We created an experimental model for the study of immunomodulatory activity of probiotic strains of lactobacilli and bifidobacteria in vitro and in vivo. We esteblished that the probiotic strains Lactobacillus acidophilus IMV B-7279, L. casei IMV B-7280, Bifidobacterium animalis VKL and B. animalis VKB, as well as different compositions based on probiotic strains might be promising for creating high-effective immune biotics with antibacterial and immune modulatory effects for treatments of infectious-and inflammatory diseases, caused by pathogenic and opportunistic microorganisms.

K e y w o r d s: lactobacilli, bifidobacteria, immunity, infection, diseases, biotech drugs.

Rapid increase in number of infectious diseases caused by pathogen and opportunistic bacteria, viruses and fungi as well as emergence of new pathogens of mainly viral nature has been observed in the world in recent years. These phenomena in their turn are caused by general decrease in organisms protection abilities, spread of immune systems imbalances (depressions or overexcitations) which are caused by environmental changes, uncontrolled use of chemical preparations of different origin including modern antibiotic preparations and formation of resistance to them, and negative changes to the normal gut microbiota $[6,10,16,28]$. Dysfunction of the immune system is directly related to increased aggressiveness of opportunistic microorganisms and can cause emergence of oncological diseases, chronic inflammatory and allergic states etc. [7, 9, 12, 26].

Taking into account a constant negative influence of environmental factors that significantly adversely affect the functioning of major systems and organs of the macroorganism, primarily the immune system, probiotics, prebiotics and probiotic products use in the treatment of patients with the most common infections is becoming increasingly important. The term "probiotics" mean pharmaceutical drugs, special foods and dietary supplements that are based on 
living cells of normal microbiota that putting a positive effect on physiological, biochemical and immune response of the host organism under natural way by optimizing and stabilizing functions of its normal microbiota through adhesive immunomodulatory and antagonistic properties $[7,8,9,11,14,15,25,27,31]$.

The most promising strains of lactobacilli (LAB) and bifidobacteria for development of probiotics are those which easily accustom to organisms, show high antagonistic activity towards pathogenic and opportunistic microorganisms and have immunomodulation properties related to activation of innate immunity and balancing cytokine, that affecting development of specific immune response [23, 27]

Today few hundreds of probiotic preparations with declared high level of immunomodulation properties able to activate immune response mainly related to induction of anti-inflammatory cytokines are presented on the pharmaceutical market of developed countries. However only few probiotic strains stored in research laboratories and only a number of ready forms of probiotic preparations are able to balance immune response mainly through synthesis of regulating anti-inflammatoty cytokines such as interlukin-10 (IL-10), transforming growth factor- $\alpha$, and induction of TLR-NF-k $\beta$ or some CDantigens expression which regulate of the immune response [23]. But the actual problem is the selection of probiotic strains and probiotic compositions with a maximum level of induction both pro- and anti-inflammatory cytokines (IL-4, IL-10, IL-12, interferon- $\gamma$, (IFN- $\gamma$ )) able to align the imbalance of Th1 / Th2 immune response in case of particular level of its disorder being a result of an infectious disease. This is the most efficient way of influencing immune response under infectious, inflammatory and other diseases. Therefore research and development of preparations based on human mucous tunics commensal microbiota able to regulate immune response of an organism without side effects which are difficult to foresee and compensate in every particular case still is one the most important tasks of modern molecular immunology and immunotherapy.

Over the last 10 years our efforts were aimed at the creating of a new research-based approaches to development of technologies for production of advanced biotechnological preparations - immunobiotics on the basis of the $\mathrm{LAB}$ and bifidobacteria which have antibacterial properties and high level ability to balance immune response by inducing cytokines of various nature under infectious and inflammatory diseases of bacterial, viral and fungal genesis. The objects of our study were Lactobacilus acidophilus IMV B-7279, L. casei IMV B-7280, deposited in the Depositary of microorganisms of the D.K. Zabolotny Institute of Microbiology and Virology, NAS of Ukraine and also Bifidobacterium animalis VKL and B. animalis VKB.

It was established that non-pathogenic, non-toxic, genetically homogeneous $L$. acidophilus IMV B-7279, L. casei IMV B-7280, B. animalis VKL and $B$. animalis VKB strains, which were not subjected to mutagenic influences and genetic transformation, are promising to create immunobiotics with antibacterial and immunomodulatory action. It was shown that the main probiotic properties of these strains of $\mathrm{LAB}$ and bifidobacteria, that allow to use them as the main component of immunobiotics, are: the ability to survive in the harsh conditions of the gastrointestinal tract; significant biosynthetic activity (ability to substantial synthesis of lactic acid, enzymes, which are associated 
with their cholesterol-lowering activity); middle and high adhesiveness to mucosal epithelium; antagonistic activity against a wide range of pathogenic and opportunistic microbiota; immunomodulatory properties. So, L. acidophilus IMV B-7279, L. casei IMV B-7280, B. animalis VKL and B. animalis VKB in vitro effectively inhibit the growth of museum and clinical pathogenic and opportunistic bacteria strains. Most sensitive to LAB and bifidobacteria antagonistic activity appeared bacteria of Staphylococcus genus. The probiotic strains L. acidophilus IMV B-7279, L. casei IMV B-7280, B. animalis VKL and $B$. animalis VKB have different sensitivity to various types of antibiotics - cephalosporins, lincosamides, fluoroquinolones, nitrofuranus, penicillins, aminoglycosides, macrolides, tetracyclines, glycopeptides, sulfonamides, karbapenems and sulfonamides that should be taken into account for developing of individual schemes of complex treatment, which involve combined use of antibiotics and probiotics [17-19, 21-24, 29].

Determination of biocompatibility of L. acidophilus IMV B-7279, L. casei IMV B-7280, B. animalis VKL and B. animalis VKB has shown that they are not antagonists, so not inhibit the growth of each other [5]. The obtained data showed that it is possible to combine these strains of LAB and bifidobacteria in different compositions with different volume ratios to obtain preparation with various probiotic properties. Immunomodulatory activity of L acidophilus IMV B-7279, L. casei IMV B-7280, B. animalis VKL and B. animalis VKB in vitro and in vivo is proved: in case of physiological norm they promoted effector functions of phagocytic system cells, induced production of varied immunoregulatory cytokines, but in vivo left unchanged phenotypic composition of spleen lymphocytes of the intact BALB/c mice. After use of these probiotic strains for treatment intact mice (at the dose of $25 \mathrm{mcl}$ in the amount of $4 \times 10^{8}$ $\mathrm{CFU} / \mathrm{ml}$ to the 7 -day schedule) the parameters of the peritoneal macrophages activity such as phagocytosis and respiratory burst were increased in different periods of observation. It was found that probiotic strains L. acidophillus IMV B-7279, L. casei IMV B-7280, B. animalis VKL or B. animalis VKB after administration to into intact mice did not cause a change in subpopulation of the spleen cells: the number of CD3+-, CD4+-, CD8+-, CD19+-cells and NKC were kept on the level of control. Increase of the immunoregulatory index in different periods of observation under the influence of L. acidophillus IMV B-7279 and B. animalis VKB indirectly indicate their potential ability to guide the development of the immune response by cell type [5, 13, 21-23].

In case of physiological norm probiotic strains did not change the proinflammatory cytokine production - tumor necrosis factor- $\alpha$ (TNF- $\alpha)$, however production of other Th1-type cytokines - interferon- $\gamma($ IFN- $\gamma$ ) and / or IL-12 production was increased and the decreasing of Th2-type cytokines IL-4 and/or IL-10 were observed in different periods of observation [19]. We have also observed the significant increasing of IgA production in all the mucosal sites including the popliteal, mesenteric lymph nodes, Peyer's patches, as well as in mucosal sites of vagina and uterus inducted by using of intravaginal implementation LAB strains into intact mice. A fundamentally new approach for preliminary selection of LAB strains with immunomodulatory properties to create immunobiotics that takes into account correlation between the degrees of rigidity of the cell wall of bacteria and their influence on the activity of phagocytic cells (ability to accumulate $\mathrm{NO} / \mathrm{NO}_{2}$ and reactogenic oxygen 
metabolites) and production of immunoregulatory cytokines were established. The rigidity of cell wall of LAB was distributed as follows: L. acidophilus IMV B-7279 > L. casei IMV B-7280. Among the strains of bifidobacteria B. animalis VKB had tougher cell wall than $B$. animalis VKL. It was found that effector functions of phagocytic system cells increased in vitro intensively under the influence of LAB strains with less rigid cell wall, which were better digested in these cells than the strains with more rigid cell wall. However, more effective activator of cytokine production (IFN- $\gamma$ and IL-12) in vitro among LAB strains appeared strains with more rigid cell wall. It is proved that L. acidophilus IMV B-7279, L. case iMV B-7280, B. animalis VKL and B. animalis VKB is biocompatible, which allows to combine these strains of LAB and bifidobacteria with different degrees of the cell wall rigidity in different composition, thereby getting probiotic preparation with specified properties [20].

Therefore, we detected in vitro and in vivo the potential of $L$. casei IMV B-7280, L. acidophillus IMV B-7279, B. animalis VKB or B. animalis VKL to guide the development of the immune response mainly by Th1-type, at least in case of physiological norm. Thus, these probiotic strains were promising to create immunobiotics with antibacterial and immunomodulatory action for treatment of infections disease, accompanied by the development of immune deficiency. In our further investigations the experimental model of the vaginal staphylococcal infection in mice BALB/c for determination of the antibacterial and immunomodulatory effect of probiotic strains of LAB and bifidobacteria was created. $S$. aureus $8325-4$ was used for creation of an experimental intravaginal staphylococcosis model because it contain the stability plasmid to gentamicin so it could be separated from other strains of staphylococci by way of cultivation on elective nutrient medium (BAIRD-PARKER-Agar, Merck, Germany) with this antibiotic. The mice received a one-time intravaginal injection of $S$. aureus $8325-4$ of $25 \mathrm{mcl}\left(2 \times 10^{8} \mathrm{CFU} / \mathrm{ml}\right)$ [5].

After a single injection of $S$. aureus 8325-4 into the vagina the occurrence of external clinical signs of infectious-inflammatory process such as discharge of yellowish-greenish color, edema and hyperemia of the vulva was observed [ 5 , 13]. Morphological features of infectious-inflammatory process in the vagina were: significant swelling of the epithelial layer, it's magnaview infiltration of polymorphonuclear leukocytes and lymphoid cells, clusters of which were found also in subepithelial areas; and moderate infiltration of inflammatory cells in the submucosa, muscular and even adventitia shell. The development of the inflammatory process at the local level was evidenced by the increase in the number TL2- and TL4-positive macrophages in the epithelium of the vaginal mucosa.

The vaginal microbiota of the infected mice was significant changed. The S. aureus 8325-4 strain was seeded out from the vagina of these mice throughout the observation period. The number of aerobic and facultative anaerobic microorganisms, staphylococci, streptococci, coliform bacteria and fungi flora after injection in vagina of the Staphylococcus infected mice were increased. These mice demonstrated the following changes in the species spectrum of the mucous layers of vagina: the number of LAB fell to its lowest level; the number of $P$. aeruginosa and $S$. aureus was increased for both of these pathogens; the number of $S$. agalactiae also was increased compared to the intact mice (data non published). 
We first found that infection of mice with S. aureus 8325-4 into vagina contributed to the development of ascending staphylococcal infections and led to changes in gut because this strain of staphylococcus was seeded out from their kidneys and intestinal contents. Unlike control group indicators, in the kidneys of Staphylococcus infected mice the number of staphylococci was increased; in a small number appeared streptococci, coliform bacteria and fungal flora in the different period of the observation. It should be noted, that from kidneys of intact mice these microorganisms were not seeded out at all. In the intestinal contents of Staphylococcus infected mice the number of staphylococci also increased, but the number of microorganisms that were plated on the elective medium for streptococci and fungal flora did not change; but $\mathrm{s}$ the number of coliform microorganisms decreased [5].

In the case of vaginal staphylococcal infection in mice an impairments of immune parametrs such as decreased activity of macrophages, reduce the number of nutural killer cells (NKC), CD3+ and CD4+ T-lymphocytes in the spleen and droped the immunoregulatory index CD4/CD8 in different periods of observation was observed. In the same time after injection of $S$. aureus 8325-4 into the vagina the imbalance of Th1/Th2 type cytokine production at local and systemic levels with a predominance of the IL-4 production and decreased production of the IL-12 were found. Established imbalance in Th2/Th1-type cytokines production can be the basis of a violation in the cellular immune response that was observed in cases of vaginal staphylococcal infection $[5,13]$.

The probiotic strains L. acidophilus IMV B-7279, L. casei IMV B-7280, $B$. animalis VKL and $B$. animalis VKB (individually) and in various compositions after the administration to Staphylococcus infected Balb/c line mice (once per day for 7 days at a dose of $5 \times 10^{6}$ cells/animal) had both antibacterial and immunomodulatory properties. It should be noted, that L. acidophilus IMV B-7279, L. casei IMV B-7280, B. animalis VKL, B. animalis VKB and their different compositions in the case of the vaginal staphylococcal infection caused the disappearance of the external visual clinical signs of infectious-inflammatory process in the vagina, as well as the gradual decrease or even the disappearance of its morphological changes in the tissue of the vagina, starting from $1^{\text {st }}$ day and during the next period of observation. Our data indicate that the injection of $L$. case $i$ IMV B-7280 into vagina and per os is more effective in the treatment of mice with vaginal staphylococcal infection, because in this scheme of LAB probiotic strain administration full normalization of the morphological structure of the vaginal wall was observed. However, morphological signs of inflammation of the vagina still remained after the injection of infected mice with other probiotic starins (data non published).

After use for treatmen of the probiotic starins the accelerate elimination of $S$. aureus 8325-4 from the vagina, kidney and intestinal contents was observed. The strains $L$. casei IMV B-7280, B. animalis VKL and B. animalis VKB had more efficient antagonistic activity against $S$. aureus 8325-4 than L. acidophilus IMV B-7279. The most effective antagonistic activity against S. aureus 8325-4 was in probiotic compositions such as L. casei IMV B-7280 B. animalis $\mathrm{VKL}-B$. animalis $\mathrm{VKB}$ and $L$. casei IMV B-7280 - B. animalis VKL - L. acidophilus IMV B-7279. 
It was established that microbiota of the vagina of infected mice normalized under the influence only of the strain L. casei IMV B-7280, and such probiotic compositions like L. acidophilus IMV B-7279 - B. animalis VKB, L. acidophilus IMV B-7279 - L. casei IMV B-7280, L. casei IMV B-7280 B. animalis VKB, L. casei IMV B-7280 - B. animalis VKB - B. animalis VKL, L. casei IMV B-7280 - B. animalis VKL - L. acidophilus IMV B-7279, L. casei IMV B-7280 - B. animalis VKB - L. acidophilus IMV B-7279. In generally, the number of aerobic and facultative anaerobic microorganisms, staphylococci, streptococci, coliform bacteria and microscopic fungi in the vagina of the Stapphylococcus infected mice after use for treatment of the L. casei IMV B-7280 and these probiotic composotions was decreased in certain periods of the observations.

Vaginal microbiota of mice infected with $S$. aureus 8325-4 that were administered for therapeutic purposes the intravaginal L. casei IMV B-7280 saw the following changes: the number of L. acidophilus and L. casei by the end of the experiment was increased, the number of $P$. aeruginosa and $S$. aureus was decreased; the number of $S$. agalactiae was dropped. So, it was detected a normalization of the microbiota spectrum in the vagina of Staphylococcus infected mice treated with probiotic strains $[1-5,13]$.

L. acidophilus IMV B-7279, L. casei IMV B-7280, B. animalis VKL, B. animalis VKB strains and their different compositions in vivo in the case of the vaginal staphylococcal infection increased functional activity of phagocytic system cells, normalized the amount of NKC, CD4+ T-lymphocytes in the spleen and immunoregulatory index CD4/CD8 [5, 13]. All of these probiotic strains and the composition L. casei IMV B-7280 - B. animalis VKB $B$. animalis VKL directed the development of the immune response by Th1type, which was confirmed by increased production of IL-12 and IFN- $\gamma$ due to impaired production of IL-4 in the system level. Under the influence of L. case $i$ IMV B-7280 the number of TLR2- and TLR4- positive macrophages in the epithelium of the vaginal mucosa of infected mice was decreased, and the local production of Th1-type cytokine - IL-12 was increased, and the synthesis of anti-inflammatory cytokines - IL-10, IL-17A was suppressed at the local levels (data non published).

In further studies probiotic strain L. casei IMV B-7280 was used in limited clinical trials for the correction of intermediate type of biocenosis of the vagina in women and to treat women with vaginal dysbiosis. Our data indicate a high clinical efficacy of L. casei IMV B-7280 in the treatment of female patients with vaginal dysbiosis and for the correction of the vaginal microbiota of women with an intermediate type, as evidenced by normalization of the number of LAB, bifidobacteria, staphylococci, streptococci, as well as the disappearance of microscopic fungi and coliform flora on the background of the normalization of the cytological picture.

As a result of our studies it was developed and approved Technical specification of Ukrain TSU 21.1-2960512097-004:2015 "Freeze-dried concentrate of probiotic microorganisms" about the use of L. acidophilus IMV B-7279, L. casei IMV B-7280, B. animalis VKL and B. animalis VKB for production of biologically active drugs, including immunobiotics [30]. The test sample of the preparation based on L. casei IMV B-7280 was received. Probiotic strain L. casei IMV B-7280 in limited clinical studies have 
demonstrated a high capacity for normalization the species composition of biocenosis of the vagina in cases of dysbiosis and vaginosis. The laboratory regulations to obtain of the "Lactokas" (PreVaLac) preparation on the basis of L. casei IMV B-7280 had been developed.

Our results confirm the validity of the requirements of the European regulatory legislation in the field of probiotics regarding the need for comprehensive studies of biological activity of both separate cultures and their combinations, which would allow for the creation of effective probiotic drugs based on monocultures of LAB and/or bifidobacteria or their various combinations. We suggest that LAB and bifidobacteria and novel strains might be an additional or supplementary therapy in the cases of differenty pathological process and may have potential for preventing wide scope of immunity-related diseases due anti-inflammatory effect. The next generation probiotics strains should be properly studied and suggested to clinical application. Translation of the obtained data on animal model to human organism may allow considering diet correction with probiotics for balancing immunity, in particular in for promotion of health based on patient profiling with relevant gut microbiome data and immune response patterns guided physiologic diet and lifestyle in the integrated vision of an interactome.

\title{
Л.М. Лазаренко ${ }^{1}$, Л.П. Бабенко ${ }^{1}$ Р.В. Бубнов О.М. Демченко ${ }^{1}$, В.М. Зоценко ${ }^{1}$, Н.В Бойко ${ }^{2}$, М.Я. Співак ${ }^{1,3}$
}

\author{
${ }^{1}$ Інститут мікробіологї і вірусологї ім. Д.К. Заболотного НАН Украӥни, \\ вул. Заболотного, 154, Київ, 03143, Украӥна \\ ${ }^{2}$ Ужсгородський національний університет Міністерства освіти і науки Украӥни, \\ вул. Підгірна, 46, Ужгород, 88000, Украӥна \\ ${ }^{3}$ ПРАТ «Діапроф», \\ вул. Світличного, 35, Київ, 04123, Украӥна
}

\section{ІМУНОБІОТИКИ - НОВІТНІ БІОТЕХНОЛОГІЧНІ ПРЕПАРАТИ 3 АНТИБАКТЕРІАЛЬНИМИ ТА ІМУНОМОДУЛЮВАЛЬНИМИ ВЛАСТИВОСТЯМИ}

Резюме

Розроблено технологію отримання новітніх біотехнологічних пробіотичних препаратів на основі попередньо відібраних та охарактеризованих штамів лактобацил і біфідобактерій, які мають антибактеріальну дію і високий рівень здатності збалансувати імунну відповідь при інфекційних і запальних захворюваннях бактеріального, вірусного та грибкового генезу шляхом індукції цитокінів різної природи. Створено експериментальні моделі для вивчення імуномодулювальної активності пробіотичних штамів лактобацил і біфідобактерій in vitro та in vivo. Встановлено, що пробіотичні штами Lactobacillus acidophilus IMB B-7279, L. casei IMB B-7280, Bifidobacterium animalis VKL та $B$. animalis VKB, а також різні композиції на основі цих пробіотичних штамів $є$ перспективними для створення високоефективних імунобіотиків з антибактеріальною та імуномодулювальною дією для лікування інфекційно-запальних захворювань, викликаних патогенними та умовно-патогенними мікроорганізмами.

Ключові слова: лактобацили, біфідобактерії, імунітет, інфекції, хвороби, біотехнологічні препарати. 


\section{Л.М. Лазаренко ${ }^{1}$, Л.П. Бабенко ${ }^{1}$ Р.В. Бубнов ${ }^{1}$, О.М. Демченко ${ }^{1}$,}

В.М. Зоценко ${ }^{1}$ Н.В Бойко ${ }^{2}$, М.Я. Спивак ${ }^{1,3}$

${ }^{1}$ Институт микробиологии и вирусологии им. Д.К. Заболотного НАН Украинь,, ул. Заболотного, 154, Киев, 03143, Украина

${ }^{2}$ Уэсгородский национальный университет, ул. Подгорная, 46, Ужгород, 88000, Украина

${ }^{3}$ ЧАО «Диапроф»,

ул. Светличного, 35, Киев, 04123, Украина

\section{ИММУНОБИОТИКИ - НОВЕЙШИЕ БИОТЕХНОЛОГИЧЕСКИЕ ПРЕПАРАТЫ С АНТИБАКТЕРИАЛЬНЫМИ И ИММУНОМОДУЛИРУЮЩИМИ СВОЙСТВАМИ}

\section{Резюме}

Разработана технология получения новейших биотехнологических пробиотических препаратов на основе предварительно отобранных и охарактеризованных штаммов лактобацилл и бифидобактерий, которые обладают антибактериальным действием и высоким уровнем способности балансировать иммунный ответ при инфекционных и воспалительных заболеваниях бактериального, вирусного и грибкового генеза путем индукции цитокинов различной природы. Созданы экспериментальные модели для изучения иммуномодулирующей активности пробиотических штаммов лактобацилл и бифидобактерий in vitro и in vivo. Установлено, что пробиотические штаммы Lactobacillus acidophilus IMB B-7279, L. casei IMB B-7280, Bifidobacterium animalis VKL и B. animalis VKB, а также различные композиции на основе этих пробиотических штаммов являются перспективными для создания высокоэффективных иммунобиотиков с антибактериальным и иммуномодулирующим действием для лечения инфекционно-воспалительных заболеваний, вызванных патогенными и условно-патогенными микроорганизмами.

Ключевые слова: лактобациллы, бифидобактерии, иммунитет, инфекции, болезни, биотехнологические препараты.

1. Babenko L.P., Lazarenko L.M., Shynkarenko L.M., Mokrozub V.V., Pidgorskyi V.S., Spivak M.Ya. The effect of lacto- and bifidobacteria composition on the vaginal microflora in cases of intravaginal staphylococcosis // Mikrobiol. Z. - 2012. - 74, N 6. - P. 68-77.

2. Babenko L.P., Lazarenko L.M., Shynkarenko L.M., Mokrozub V.V., Pidgorskyi V.S., Spivak M.Y. The effect of lacto- and bifidobacteria in monoculture on the vaginal microflora in norm and in cases of intravaginal Staphylococcosis // Mikrobiol. Z. - 2012. - 74, N 6. - P. 80-89.

3. Babenko L.P., Lazarenko L.M., Demchenko O.A., Konarbaeva Z.K., Spivak M.Ja. Antibacterial activity of Lactobacillus casei IMV B-7280 in cases of experimental urogenital staphylococcosis // Biotechnologia Acta - 2015 - 8, N 3 . - P. 95-103.

4. Babenko L.R., Lazarenko L.M., Shynkarenko L.M., Mokrozub V.V., Pidgorskyi V.S., Spivak M.J. The effect of lacto- and bifidobacteria in monoculture on the vaginal microflora in norm and in cases of intravaginal staphylococcosis // Mikrobiol Z. - 2013. - 75, N 3. - P. 46-55.

5. Babenko L.P. The effect of probiotic strains of lactobacilli and bifidobacteria on a range of microbiota and immunologic reactivity of the organism in cases of staphylococcal infection of the urogenital tract: Synopsis of manuscript...PhD in biology - Kyiv, 2015. - 24 p. [Ukrainian]. 
6. Frey Tirri B. Antimicrobial topical agents used in the vagina // Curr. Probl. Dermatol. 2011. - N 40. - P. 36-47. 2

7. Gill H.S., Guarner F. Probiotics and human health: a clinical perspective // Postgrad. Med. J. - 2004. - 80, N 947. - P. 516-526. 8

8. Gill H.S., Rutherford K.J. Viability and dose response studies on the effects of the immunoenhancing lactic acid bacterium Lactobacillus rhamnosus in mice // $\mathrm{Br}$. J. Nutr. - 2001. - 86. - N 2. - P. 285-289. 13

9. Grover S., Rashmi H.M, Srivastava A.K., Batish V.K. Probiotics for human health - new innovations and emerging trends // Gut Pathogens. - 2012. - 4, 15. doi: 10.1186/17574749-4-15 9

10. Hay P.E. Bacterial vaginosis and miscarriage // Curr. Opin. Infect. Dis. - 2004. - 17, N 1. - P. 41-44.1

11. Herias M.V., Hessle C., Telemo E., Midtvedt T., Hanson L.A., Wold A.E. Immunomodulatory effects of Lactobacillus plantarum colonising the intestine of gnotobiotic rats // Food Res. Int. - 1999. - 116, N 2. - P. 283-290. 14

12. Hoesl C.E., Altwein J.E. Review The Probiotic Approach: An Alternative Treatment // Option in Urology. - 2005. - 47, N 3. - P. 288-296. 6

13. Lazarenko L., Babenko L., Sichel L.S., Pidgorskyi V., Mokrozub V., Voronkova O., Spivak M. Antagonistic action of lactobacilli and bifidobacteria in relation to Staphylococcus aureus and their influence on the immune response in cases of intravaginal Staphylococcosis in mice // Probiotics Antimicrob. Proteins. - 2012. - 4, N 2. - P 78-89.

14.Lozupone C.A., Knight R. Unifrac: A New Phylogenetic Method For Comparing Microbial Communities // Appl. Envrionm. Microbiol. - 2005. - 7, N 1. - P. 8228 8235. 11

15. Lu L., Walker W.A. Pathologic and physiologic interactions of bacteria with the gastrointestinal epithelium // Am. J. Clin. Nutr. - 2001. - 73, N 6. - P. 1124S-1130S. 15

16. Martin H.L., Richardson B.A., Nyange P.M., Lavreys L., Hillier S.L., Chohan B., Mandaliya K., Ndinya-Achola J.O., Bwayo J., Kreiss J. Vaginal lactobacilli, microbial flora, and risk of human immunodeficiency virus type 1 and sexually transmitted disease acquisition // J. Infect. Dis. - 1999. - 180, N 6. - P. 1863-1868. 3

17. Mokrozub V.V., Lazarenko L.M., Babenko L.P., Shinkarenko L.M., Spivak M.Ya. Antibacterial and immunomodulating properties of lacto- and bifidobacteria strains at experimental staphylococcal infection // Biotech. Acta. - 2012. - 5, N 2. - P. 98-104 [Ukrainian].

18. Mokrozub V.V., Lazarenko L.M., Babenko L.P., Shynkarenko-Sichel L.M., Olevinska Z.M., Timoshok N.O., Pidgorskyi V.S., Spivak M.Ya. Effect of probiotic strains of lacto- and bifidobacteria on the activity of macrophages and other parameters of immunity in cases of staphylococcosis // Mikrobiol Z. - 2012. - 74, N 6. - P. 78-86.

19. Mokrozub V.V. Effectiveness of lacto- and bifidobacteria strains and cytokine drugs in experimental staphylococcal infection: Synopsis of manuscript...PhD in biology Kyiv, 2014. - 22 p.

20. Mokrozub Viktoria V., Liudmyla M. Lazarenko, Liubov M. Sichel, Lidia P. Babenko, Petro M. Lytvyn, Olga M. Demchenko, Yulia O. Melnichenko, Nadiya V. Boyko, Bruno Biavati, Diana DiGioia, Rostyslav V. Bubnov and Mykola Ya Spivak. The role of beneficial bacteria wall elasticity in regulating innate immune response // EPMA Journal. 2015. - 6, N 1:13 doi:10.1186/s13167-015-0035-1. 
21. Pat. 92983 of Ukraine, C12N 1/20 (2011.01), C12R 1/225 (2006.01), A61K 37/02 (2006.01). Strain Lactobacillus delbrueckii subsp. bulgaricus IMV B-7281 - phagocytes activator / Spivak M.Ya., Shynkarenko L.M., Pidgorskyi V.S., Gorchakov V.Ju., Starovoitova S.O., Lazarenko L.M., Tymoshok N.O. // Bul. - 2010. - N $24-6$ p. [Ukrainian].

22. Pat. 93132 of Ukraine, C12N 1/20 (2011.01), C12R 1/23(2006.01), A61K 35/74(2006.01). Strain Lactobacillus acidofillus IMV B-7279 - inductor of endogenous interferon type I / Spivak M.Ya., Shynkarenko L.M., Pidgorskyi V.S., Gorchakov V.Ju., Starovoitova S.O., Lazarenko L.M., Tymoshok N.O.// Bul. - 2011. - N 1 - 6 p. [Ukrainian].

23. Pat. 93133 of Ukraine, C12N 1/20 (2006/01), C12R 1/245 (2006/01), A61K 37/02(2006/01) Lactobacillus casei IMV B-7280 - inductor of «late» interferon and macrophage activator / Spivak M.Ya., Shynkarenko L.M., Pidgorskyi V.S., Gorchakov V.Ju., Starovoitova S.O., Lazarenko L.M., Tymoshok N.O. // Bul. - 2011. - N 1. - 6 p. [Ukrainian].

24. Pat. 98881 Ukraine, C12N 1/00 (2015.01 Lactobacillus casei IMV B-7280 - strain for creation a probiotic preparation with antibacterial and immunomodulatory action / M.Ya. Spivak, L.M. Lazarenko, O.A. Demchenko, L.P. Babenko // Bul. - 2015. N 9. -6 p. [Ukrainian].

25. Probiotics: immunobiotics and immunogenics / Editor Haruki Kitazawa, Julio Villena, Susana Alvares - USA, CRC Press, 2014. - 402 p. 16

26. Reid G., Bruce A.W., Talor M. Instillation of Lactobacillus and stimulation of indigenous organisms to prevent recurrence of urinary tract infections // Microecol. Ther. 1995. - 23. - P. 32-45. 5

27. Rostyslav V. Bubnov, Mykola Ya. Spivak, Liudmyla M. Lazarenko, Alojz Bomba and Nadiya V. Boyko Probiotics and immunity: provisional role for personalized diets and disease prevention // EPMA Journal. -2015. - 6, N 1:14 doi:10.1186/s13167015-0036-0.

28. Schwebke J.R. Gynecologic consequences of bacterial vaginosis // Obstet. Gynecol. Clin. North. Am. - 2003. - 30, N 4. - P. 685-694. 4

29. Staravoitova S.A., Babenko L.P., Timoshok N.A., Shynkarenko L.N., Lazarenko L.N., Spivak N.Y. Cholesterol-lowering activity of lactic acid bacteria probiotic strains in vivo // Mikrobiol Z. - 2012. - 74, N 3. - C. 78-85.

30. Technical specification of Ukraine, TSU 21.1-2960512097-004:2015 «Freeze-dried concentrate of probiotic microorganisms» / Spivak M.Ya, Lazarenko L.M., Babenko L.P., Demchenko O.A., Timoshok N.O., Lyubima U.O., Mokrozub V.V., 2015 p. [Ukrainian].

31. Turnbaugh P.J., Hamady M., Ley R., Fraser C., Knight R., Gordon J.I. The human microbiome project: exploring the microbial side of ourselves // Nature. - 2007. - 449, N 7164. - P. 804-810. 10 